unbroken, was copiously coated with ice crystals above, but only scantily underneath; but where the ice had been broken so that the cavity beneath it had communicated freely with the open air, the crop of ice crystals was equally copious on both sides. A large hollow iron roller, 24 inches in diameter, had a copious crop of ice crystals on the upper surface, but little on the sides. Underneath, however, it had a coating of ice which extended about an inch from the point at which it rested on the earth, and then ended abruptly.

These observations seem to show that for the formation of hoar-frost, and inferentially also of dew, upon solid bodies, two factors are necessary, viz. (I) a sufficient cooling of the bodies by radiation below the temperature of the surrounding air; and (2) a supply of watery vapour in the air; and that within certain limits an excess of one of these factors may compensate for a deficiency of the other. Thus upon the top twigs, on the uppermost stones in the heaps, and on the upper surface of the iron roller-all these bodies being freely exposed to radiation, and not directly connected with the warm earth-a copious deposit of hoar frost took place ; and this deposit, it is to be remarked, must have been condensed from the vapour diffused in the layers of air in contact with those bodies, and not from that issuing from the earth. Vapour from the ground could not pass through the impervious iron roller to reach the upper surface; it may indeed be supposed to have passed round the circumference, but the sides of the roller were, as I have said, comparatively free from hoar-frost. On the other hand, the under sides of the stones, and of the roller, though to a considerable extent protected from radiation, had on them a deposit of ice, seemingly condensed, as Mr. Aitken supposes, from the vapour exhaled from the comparatively warm ground beneath them.

The scantier deposit of hoar-frost upon the under surface of the "cat's ice" when unbroken than when broken is, I presume, due to the more rapid cooling of the ice when the space beneath it communicates with the open air, than when closed.

\section{January 19}

\section{Clouds and Upper Wind-Currents over the Atlantic \\ Doldrums}

THE first of the two following weather sections across the Atlantic doldrums was taken in June and July last on board the s.s. Tongariro, during her voyage from Rio Janeiro to Teneriffe.

Practically clouds in these latitudes may be taken as belonging to three levels : a small cumulus, low down; a middle layer of some stratiform cloud; and a high-level cirrus. Any one of these may appear by itself, or all may be present simultaneously. The depth of the various air-currents which drive these clouds, $I$ take to be of great importance in any general theory of the circulation of the atmosphere in the equatorial regions.

Space will not permit me to give here the details of each day's observations, but the results may be briefly stated thus: South of the equator, the low or middle clouds over the southeast trade, which we picked up in $10^{\circ} \mathrm{S}$. lat., invariably came from some point to the right of the surface-wind, when you stood with your back to it, i.e. if the surface-wind was south-east the clouds would drive from about east-south-east. This is the usual rotation of upper currents in the southern hemisphere.

But, north of the Line, when for reasons which cannot be discussed here, the south-east trade did not turn to south-west, as might have been expected, the upper currents continued to follow the rotation of the southern, and not that of the northern hemisphere, that is to say, the upper currents over the southeast surface-wind continued to come from some more easterly point. In the "doldrums," also, which extended from about $8^{\circ}$ to $13^{\circ} \mathrm{N}$., the same rule obtained, and the middle cloud-layer over some "cat's-paws" of south-east wind drove from the east.

In the north-east trade I only got one unsatisfactory observation in $22^{\circ} \mathrm{N}$., $19^{\circ} \mathrm{W}$., which gave a middle layer of north-northeast wind over an east-north-east surface trade. This is contrary to what might have been expected.

The second section was taken in December last on board the s.s. Drummond Castle, during part of her voyage between Lisbon and Cape Town, with much better appliances for observing clouds than on my former voyage.

In the north-east trade, from $30^{\circ} \mathrm{N}$. lat. down to the doldrums in $5^{\circ} \mathrm{N}$., the upper layers of cloud invariably came from some point to the left of the surface-wind. When you stood with your back to it, i.e. if the surface-wind was from north-east, the higher clouds would come from east, or south-east, or even south by west. This is the usual rotation of upper wind-currents in the northern hemisphere. As far north as $20^{\circ} \mathrm{N}$. the middle clouds came from south by west, and in $10^{\circ} \mathrm{N}$. this current had descended to the level of the low cumulus, and the middle clouds drove from west.

But as we touched the doldrums in $5^{\circ} \mathrm{N}$., a totally different wind-system became apparent. Over the oily calm of that district I could just detect, through the universal haze and gloom, a middle current from the east; and when, in a few hours, we picked up the south-west monsoon of the Gulf of Guinea, here coming from south by west, the low clouds drove from southeast. This continued till we reached the Line, and the single observation which I got of high cirrus in $\mathrm{I}^{\circ} \mathrm{N}$. lat. showed an easterly current at that level. Thus, for $8^{\circ} \mathrm{N}$. of the equator the rotation of the upper winds was that proper to the southern hemisphere, for south-cast and east were over a south-west surface-wind instead of west or north-west, as might have been expected. This is the more curious, because the surface-wind has the south-west set proper to the northern hemisphere.

But the greatest interest of this last observation is to be found in the extraordinary analogy which the wind-system over the Gulf of Guinea presents to the wind-system over the northwest monsoon in the Indian Ocean, which I discovered last spring, and described in a letter to NATURE of October 29, 1885 (p. 624). In that region I found that as the north-east monsoon crosses the Line and turns to the north-west, the upper currents are those proper to the northern hemisphere, that is to say the low and high layers of cloud come from north and east respectively. Now we see that both in the Gulf of Guinea and midAtlantic, as the south-east trade crosses the Line, it carries the rotation of the higher currents, proper to itself, up to the doldrums.

After crossing the equator in the Drummond Castie the wind turned to south by east or south-south-east, and as far as $18^{\circ} \mathrm{S}$., beyond which we need not follow them, the upper currents were either identical in direction with the surface-wind, or else a very little more easterly - that is, they followed the normal rotation of their hemisphere.

In conclusion, I may point out another very important result of these observations as far as they have gone yet:- The highest current between the equator and the doldrums is always from some point near the east, whatever the westerly set of the surface-wind may be. I have had no opportunity of estimating the velocity of this current, but the impression on my mind has been that it is not apparently very rapid, though, of course, the height is very considerable.

Cape Town, December I8, 1885

\section{Ventilation}

HAVING read your late article on ventilation, and letters referring thereto, I think it may be of interest to your readers to know something of what we have done in this quarter. Since the year 1877 we have had in Dundee a number of schools and other buildings ventilated and heated by propelling large volumes of heated air into the rooms with a small-power engine.

The system, as now generally introduced, is as follows :Rotary air-pumps, or a Blackman air-propeller, driven by a small gas-engine, are placed in the basement floor. The air is conducted thither by flues from an altitude of 30 feet, so as to be as free from dust and other impurities as possible. This cold air is discharged into large wooden flues under the ground floor, which are painted with asbestos paint. Running parallel to these flues are others containing hot-water high-pressure pipes, about $\mathbf{I}_{8}^{3}$ inches in diameter. These hot flues are divided into air-tight sections, suitable for the heating of the different rooms. The air from the cold flue passes into the different sections of the hot flue, from which again it passes out, heated, into the different rooms, about 5 feet from the floor, by long and narrow flues, so that it may be well diffused. Each room has its own exhaust-flue or flues, reaching within $I_{2} \frac{1}{2}$ feet of the floor, and passing into the space between the upper-floor ceiling and the roof. This space is made into a large flue, into which all the foul air from the different rooms passes. On the roof there are constructed one or more square shafts, with fixed louvre boards on each of the four sides. Inside the louvres are fixed valveframes covered with a large number of light waterproof cloth 